\title{
Analisis Akuntabilitas Pendapatan Pajak Daerah pada Dinas Pendapatan Pengelolaan Keuangan Aset Daerah Kota Palopo
}

\author{
Andika Rusli ${ }^{1}$ \\ Saharuddin $^{2}$ \\ Surianti $^{3}$
}

No. HP $085242438738^{1}, 081342512379^{2}$

${ }^{1}$ Alamat Korespondensi: Jl. Yos Sudarso

Email:

\begin{abstract}
Abstrak
Penelitian ini bertujuan untuk mengetahui laporan pertanggungjawaban pajak daerah dalam rangka mengelola dana dengan sistem desentralisasi secara transparan, efisien, efektif dan dapat dipertanggungjawabkan. Jenis penelitian ini adalah deskriptif kualitatif. Adapun pengumpulan data yang dilakukan oleh penulis adalah dengan metode wawancara terhadap karyawan Dinas Pendapatan Pengelolaan Keuangan dan Aset Daerah Kota Palopo.
\end{abstract}

Kata kunci: Akuntabilitas, dan Pajak Daerah.

\section{Pendahuluan}

Pajak merupakan kontribusi wajib kepada negara yang terutang oleh orang pribadi atau badan yang bersifat memaksa berdasarkan Undang-Undang, dengan tidak mendapat timbal balik secara langsung dan digunakan untuk keperluan negara bagi sebesar-besarnya kemakmuran rakyat (Pasal 1 angka 1 UU No 6 Ta hun 1983 sebagaimana telah disempurnakan terakhir dengan UU No.28 Tahun 2007). Di Indonesia, pajak merupakan salah satu penerimaan pendapatan negara yang memiliki kontribusi yang sangat besar terhadap pendapatan nasional.

Pajak dalam pengelolaannya, ada beberapa pajak yang masuk ke pemerintah pusat dan ada yang masuk ke daerah-daerah. Pajak yang pengelolaannya masuk ke dalam pemerintah pusat antara lain: Pajak Penghasilan (PPh), Pajak Pertambahan Nilai (PPN), Pajak Penjualan atas Barang Mewah (PPn BM), Pajak Bumi dan Bangunan (PBB), Bea Materai, dan Bea Perolehan Hak atas Tanah dan Bangunan (BPHTB). Sedangkan pajak yang dikelola dan dipungut oleh Pemerintah Daerah meliputi Pajak Provinsi (Pajak Kendaraan Bermotor, Bea Balik Nama Kendaraan Bermotor, Pajak Bahan Bakar Kendaraan Bemotor, dll) dan Pajak Kabupaten/Kota (Pajak Hotel, Restoran, Reklame, Penerangan Jalan, Parkir, Pajak Pengambilan Bahan Galian Golongan C, dll). Bea Perolehan Hak atas Tanah dan Bangunan merupakan komponen penyumbang Pendapatan Asli Daerah (PAD).

Pelaksanaan UU No.22 Tahun 1999 dan UU No.25 Tahun 1999 telah menyebabkan perubahan yang mendasar mengenai pengaturan hubungan Pusat dan Daerah, khususnya dalam bidang administrasi pemerintahan maupun dalam hubungan keuangan antara Pemerintah Pusat dan Daerah, yang dikenal sebagai era otonomi daerah. Dalam rangka meningkatkan kemampuan keuangan daerah agar dapat melaksanakan otonomi, Pemerintah melakukan berbagai kebijakan perpajakan daerah, diantaranya dengan 
menetapkan UU No.34 Tahun 2000 tentang perubahan atas UU No.18 Tahun 1997 tentang

Pajak Daerah dan Retribusi Daerah. Pemberian kewenangan dalam pengenaan pajak dan retribusi daerah, diharapkan dapat lebih mendorong Pemerintah Daerah terus berupaya untuk mengoptimalkan PAD, khususnya yang berasal dari pajak daerah dan retribusi daerah.

Walaupun baru satu tahun diberlakukannya Otonomi Daerah sebagaimana diamanatkan dalam UU No.22 Tahun 1999 dan UU No.25 Tahun 1999 serta peraturan perundangundangan pendukung lainnya, berbagai macam respon timbul dari daerah-daerah. Diantaranya ialah bahwa pemberian keleluasaan yang diberikan kepada Pemerintah Daerah untuk meningkatkan PAD melalui pajak daerah dan retribusi daerah berdasarkan UU No.34 Tahun 2000 telah memperlihatkan hasil yang menggembirakan yaitu sejumlah daerah berhasil mencapai peningkatan PAD-nya secara signifikan. Namun, kreativitas Pemerintah Daerah yang berlebihan dan tak terkontrol dalam memungut pajak daerah dan retribusi daerah, akan menimbulkan dampak yang merugikan bagi masyarakat dan dunia usaha, yang pada gilirannya menyebabkan ekonomi biaya tinggi. Oleh karena itu UU No.34 Tahun 2000 tetap memberikan batasan kriteria Pajak Daerah dan Retribusi yang dapat dipungut oleh Pemerintah Daerah.

Pelaksanaan otonomi daerah di Indonesia pada tahun 2001 memunculkan jenis akuntabilitas baru, sesuai dengan UU Nomor 22 Tahun 1999 dan UU Nomor 25 Tahun 1999. Dalam hal ini terdapat tiga jenis pertanggungjawaban keuangan daerah yaitu (1) pertanggungjawaban pembiayaan pelaksanaan dekonsentrasi, (2) pertanggungjawaban pembiayaan pelaksanaan pembantuan, dan (3) pertanggungjawaban Anggaran Pendapatan dan Belanja Daerah (APBD). Sementara di tingkat pemerintah pusat, pertanggungjawaban Keuangan tetap dalam bentuk pertanggungjawaban Anggaran Pendapatan dan Belanja Negara (APBN). Saat ini di Indonesia sedang dilakukan persiapan penyusunan suatu standar akuntansi pemerintahan yang lebih baik serta pembicaraan yang intensif mengenai peran akuntan publik dalam memeriksa keuangan negara maupun keuangan daerah. Namun tampak bahwa akuntabilitas pemerintahan di Indonesia masih berfokus pada sisi pengelolaan Keuangan Negara atau Daerah.

Undang-undang No. 32 tahun 2004 sebagai pengganti Undang-undang No. 22 tahun 1999 tentang Pemerintah Daerah dan Undangundang No. 33 tahun 2004 sebagai pengganti Undang-undang No. 25 tahun 1999 tentang perimbangan Keuangan antara Pemerintah Pusat dan Daerah menjadi landasan yuridis bagi pengembangan otonomi daerah di Indonesia. Otonomi daerah merupakan upaya pemberdayaan daerah dalam pengambilan keputusan daerah secara lebih leluasa untuk mengelola sumber daya yang dimiliki sesuai dengan kepentingan, prioritas dan potensi daerah sendiri. Dengan adanya otonomi daerah, pengelolaan keuangan sepenuhnya berada di tangan pemerintah daerah. Sejalan dengan pelaksanaan otonomi daerah, diperlukan sistem akuntansi yang baik, karena sistem akuntansi merupakan pendukung terciptanya pengelolaan keuangan daerah yang acc ountable, dalam 
rangka mengelola dana dengan sistem desentralisa si secara transparan, efesien, efektif, dan dapat dip ertanggungjawabkan. Tujuan pertanggungjawaban yaitu memberikan informasi keuangan yang lengkap, cermat dalam bentuk dan waktu yang tepat, yang berguna bagi pihak yang bertanggung jawab terhadap operasi unit-unit Pemerintahan.

\section{Metode Penelitian}

penelitian ini penulis melakukan penelitian pada DPPKAD Kota Palopo. Jenis dan sumber data yang digunakan yaitu data primer dan sekunder. Sedangkan metode pengumpulan data yang digunakan yaitu wawancara dan studi kepustakaan.

Metode yang digunakan dalam penelitian ini adalah metode Deskriptif Kualitatif yaitu metode yang digunakan dengan cara mengklasifikasikan, disusun secara kualitatif agar dapat diperoleh kejelasan masalah yang akan dibahas.

\section{Hasil Penelitian dan Pembahasan}

\section{Pembahasan}

\section{Analisis Pendapatan Pajak Daerah}

Kemampuan Pajak Daerah yang dimiliki setiap daerah merupakan salah satu indikator kesiapan pemerintah daerah dalam berotonomi daerah. Oleh karena itu perolehan pajak daerah diarahkan untuk meningkatkan pendapatan Asli Daerah yang digunakan untuk menyelenggararakan otonomi daerah yang secara konseptual diharapkan memiliki kemampuan yang nyata dan bertanggung jawab. Tuntutan kemampuan yang nyata ini diharapkan bersumber dari kemampuan yang menyiasiati pendapatan pajak daerah melalui upaya-upaya yang dapat dilakukan psehingga terjadi peningkatan dari waktu kewaktu.

Menurut Undang-undang RI No.32 tahun 2004 tentang pemerintahan daerah pasal 1 ayat 15 diungkapkan pengertian pendapatan daerah yaitu: pendapatan daerah adalah semua hak daerah yang diakui sebagai penambah nilai kekayaan bersih dalam periode tahun anggaran yang bersangkutan. Setelah sumber pendapatan daerah dapat dikenai pajak, maka perlu juga dipertimbangkan apakah suatu pajak telah didapat secara efektif digali, dikenakan, dinilai atau dipungut tersebut maupun administrasi oleh Pemerintah Daerah. Teori development from below, berpendapat bahwa orang akan lebih bersedia membayar pajak kepada Pemerintah Daerah dari pada kepada Pemerintah Pusat kareana mereka dapat secara mudah melihat manfaat langsung dalam pembangunan di daerah mereka (Davey, 2003).

Teori development from below, yang dikemukakan tersebut menunjukkan bahwa masyarakat lebih cenderung mau membayar pajak karena kedekatannya dengan manfaat yang diperoleh dari membayar pajak tersebut. Orang akan lebih bersedia membayar pajak kepada Pemerintah Daerah daripada kepada Pemerintah Pusat merupakan hal yang logis karean Pemerintah Daerah juga lebih dekat jika dibandingkan dengan Pemerintah Pusat yang kadang mereka tidak dapat melihat manfaat langsung secara mudah dalam pembangunan didaerah mereka. Masalah pajak adalah masalah negara dan setiap orang yang hidup dalam suatu negara berurusan dengan pajak sehingga masalah pajak juga menjadi masalah keseluruhan rakyat negara tersebut. Dengan demikian setiap orang sebagai anggota masyarakat 
suatu negara harus mengetahui segala permasalahan yang berhubungan dengan pajak, baik mengenai asas-asasnya, jenis-jenis pajak yang berlaku, tata cara pembayaran pajak serta hak dan kewajiban sebagai wajib pajak.

Pajak sebagaimana dinyatakan UndangUndang Nomor 18 Tahun 1997 yang kemudian disempurnakan dalam Undang-Undang Nomor 34 Tahun 2000 dan mengalami perubahan menjadi Undang-undang Nomor 28 Tahun 2009 tentang Pajak Daerah dan Retribusi Daerah menyatakan bahwa pajak merupakan perwujudan kewajiban kenegaraan yang merupakan sarana dan peran pembiayaan negara dan pembangunan nasional. Pajak juga merupakan penarikan atas sumber daya ekonomi oleh pemerintah kepada warga negara yang digunakan untuk melaksanakan tugas Pemerintah atau melayani kepentingan masyarakat.

Kota Palopo merupakan sebagai daerah otonomi dalam melaksanakan pembangunan, menganut azas-azas desentralisasi yang diwujudkan dalam bentuk prakarsa baik dalam menentukan kebijakan, perencanaan, pelaksanaan dan segi pembiayaan maupun perangkat pelaksanaannya.

Kontribusi pendapatan pajak Hotel, pajak restoran, pajak hiburan, pajak reklame, masih sangat minim. Ini dapat dilihat dari tiga (3) tahun prosentase kontribusinya dibawa $10 \%$. Target dan realisasi tahun 2010-2012 ini disusun berdasarkan jumlah tahun target, tahun bulanan,realisasi (s/d bulan lalu,bulan ini, dan s/d bulan ini). Jumlah angka yang tercantum dalam realisasi PAD ini mencakup semua penerimaan pajak daerah yang masuk dan dikeluarkan dari bendahara umum daerah, khusus untuk pengisian kas yang diberikan kepada pemegang kas, realisasinya berdasarkan atas pengesahan pertanggungjawaban.

Untuk mengetahui bagaimana perkembangan prosentase pajak hotel, pajak restoran dan pajak reklame terhadap pajak daerah, maka dapat dilihat dari perkembangan target dan realisasi PAD yang dikelola unit kerja DPPKAD pada tahun 2010. Untuk lebih jelasnya dapat dilihat pada tabel sebagai berikut:

Tabel 1

Analisis Pajak Daerah tahun 2010

\begin{tabular}{|l|c|c|c|}
\hline \multicolumn{1}{|c|}{ Uraian } & Target & Realisasi & \% Pertumbuhan \\
\hline Pajak Hotel & Rp. 130.224 .000 & Rp. 179.072 .588 & $37,51 \%$ \\
\hline Pajak restoran & Rp. 703.636 .000 & Rp. 923.218 .399 & $31,21 \%$ \\
\hline Pajak Reklame & Rp. 400.733 .000 & Rp. 340.708 .953 & $(14,96) \%$ \\
\hline
\end{tabular}

Sumber data : Kantor DPPKAD Kota Palopo 
Dengan melihat tabel di atas maka untuk tahun 2010 dapat dijelaskan bahwa:

1. Target tahunan pajak hotel adalah sebesar 130.224.000, sementara nilai realisasinya adalah sebesar 179.072.588. Nilai ini menunjukkan bahwa penerimaan yang terealisasi berada di atas yang dianggarkan. Hal ini menunjukkan bahwa ada kenaikan penerimaan pajak hotel sebesar 48.848 .588 atau setara dengan $37,51 \%$ dari yang ditargetkan. 179.072.588, maka besar prosentase adalah $137,51 \%$.

2. Target tahunan pajak restoran adalah sebesar 703.636.000, sementara nilai realisasinya adalah sebesar 923.218.399. nilai ini menunjukkan bahwa penerimaan yang terealisasi berada di atas yang dianggarkan. Hal ini menunjukkan bahwa ada kenaikan penerimaan pajak hotel sebesar 219.582.399 atau setara dengan $31,21 \%$ dari yang ditargetkan.
3. Target tahunan pajak reklame adalah sebesar 400.733.000, sementara nilai realisasinya adalah sebesar 340.706.700. nilai ini menunjukkan bahwa penerimaan yang terealisasi berada dibawah yang dianggarkan. Hal ini menunjukkan bahwa ada penerunan penerimaan pajak reklame sebesar 60.024.047 atau setara dengan 14,98\% penurunan dari yang ditargetkan.

4. Untuk tahun 2010, meskipun nilai realisasi pajak reklame berada dibawah yang ditargetkan, akan tetapi tahun 2010 nilai tambahan atau andil yang diperoleh dari yang ditargetkan sebesar $38,37 \%$. Nilai ini merupakan kontribusi dari pajak hotel dan pajak restoran dikurangi dengan nilai kekurangan pajak reklame dapat ditutupi ooleh kontribusi pajak hotel dan restoran sehingga pada tahun2010 ada kontribusi seebesar 38,37\% dari pajak hotel dan restoran setelah dikurangi dengan kekurangan dari yang dianggarkan untuk pajak reklalme.

Tabel 2

Analisi Pajak Daerah Tahun 2011

\begin{tabular}{|l|l|l|c|}
\hline \multicolumn{1}{|c|}{ Uraian } & \multicolumn{1}{|c|}{ Target } & \multicolumn{1}{c|}{ Realisasi } & \% Pertumbuhan \\
\hline Pajak Hotel & Rp.130.224.000 & Rp. 147.548 .739 & $13,30 \%$ \\
\hline Pajak restoran & Rp.703.636.000 & Rp.1.009.856.860 & $43,52 \% \%$ \\
\hline Pajak Reklame & Rp.400.733.000 & Rp. 247.469 .911 & $(38,25 \%)$ \\
\hline
\end{tabular}

Sumber data : Kantor DPPKAD Kota Palopo 
Dengan melihat tabel diatas maka untuk tahun 2011 dapat dijelaskan bahwa:

1. Target tahunan pajak hotel adalah sebesar 130.224.000, sementara nilai realisasinya adalah sebesar 147.548.739. Nilai ini menunjukkan bahwa penerimaan yang terealisasi berada diatas yang dianggarkan. Hal ini menunjukkan bahwa ada kenaikan penerimaan pajak hotel sebesar 17.324.739 atau setara dengan $13,30 \%$ dari yang ditargetkan.

2. Target tahunan pajak restoran adalah sebesar 703.636.000 sementara nilai realisasinya adalah sebesar 1.009.856.860. nilai ini menunjukkan bawha penerimaan yang terealisasi berada diatas yang dianggarkan. Hal ini menunjukkan bahwa ada kenaikan penerimaan pajak restoran sebesar 306.220.860 atau setara dengan 43,52\% dari yang ditargetkan.

3. Target tahunan pajak reklame adalah sebesar 400.733.000 sementara nilai realisasinya adalah sebesar 247.469.911. nilai ini menunjukkan bahwa penerimaan yang terealisasi berada di bawah yang dianggarkan. Hal ini menunjukkan bahwa ada penurunan penerimaan pajak reklame sebesar 15.363.089 atau setara dengan $38,25 \%$ penurunan dari yang ditargetkan.

4. Untuk tahun 2011, meskipun nilai realisasi pajak reklame berada dibawah yang ditargetkan, akan tetapi tahun 2011 nilai tambahan atau andil yang diperoleh dari yang ditargetkan sebesar 16,57\%. Nilai ini merupakan kontribusi dari pajak hotel dan pajak restoran dikurangi dengan nilai kekurangan pajak reklame dari yang ditargetkan. Kekurangan dari nilai pajak reklame dapat ditutupi oleh kontribusi pajak hotel dan restoran sehingga pada tahun 2011 ada kontribusi sebesar $16,57 \%$ dari pajak hotel dan restoran setelah dikurangi dengan kekurangan dari yang dianggarkan untuk pajak

Tabel 3

Analisi Pajak Daerah Tahun 2012

\begin{tabular}{|l|l|l|c|}
\hline \multicolumn{1}{|c|}{ Uraian } & \multicolumn{1}{|c|}{ Target } & \multicolumn{1}{c|}{ Realisasi } & \% pertumbuhan \\
\hline Pajak hotel & Rp.130.224.000 & Rp. 150.371 .591 & $15,47 \%$ \\
\hline Pajak Restoran & Rp.703.636.000 & Rp.1.255.606.544 & $78,45 \%$ \\
\hline Pajak Reklame & Rp.400.733.000 & Rp. 230.617.920 & $(42,45 \%)$ \\
\hline
\end{tabular}

Sumber data : Kantor DPPKAD Kota Palopo 
Dengan melihat tabel diatas maka untuk tahun 2012 dapat dijelaskan bahwa:

1. Target tahunan pajak hotel adalah sebesar 130.224.000, sementara nilai realisasinya adalah sebesar 150.371.591. Nilai ini menunjukkan bahwa penerimaan terealisasi berada di atas yang dianggarkan. Hal ini menunjukkan bahwa ada kenaikan penerimaan pajak hotel sebesar 20.147.591 atau setara dengan $15,47 \%$ dari yang ditargetkan.

2. Target tahunan pajak restoran adalah sebesar 703.636.000 sementara nilai realisasinya adalah sebesar 1.255.606.544 nilai ini menunjukkan bahwa penerimaan yang terealisasi berada di atas yang dianggarkan. Hal ini menunjukkan bahwa ada kenaikan penerimaan pajak restoran sebesar $551,970.544$ atau setara dengan $78,45 \%$ dari yang ditargetkan.

3. Target tahunan pajak reklame adalah sebesar 400.733.000, sementara nilai realisasinya adalah sebesar 230.617.920. Nilai ini menunjukkan bahwa penerimaan yang terealisasi ada penurunan penerimaan pajak reklame sebesar 170.115 .080 atau setara dengan $42,45 \%$ penurunan dari yang ditargetkan.

4. Untuk tahun 2012, meskipun nilai realisasi pajak reklame berada dibawah yang ditargetkan, akan tetapi tahun 2012 nilai tambahan atau andil yang diperoleh dri yang ditargetkan sebesar $51,47 \%$. Nilai ini merupakan kontribusi dari pajak hotel dan pajak restoran dikurangi dengan nilai kekurangan dari nilai pajak reklame dapat ditutupi oleh kontribusi pajak hotel dan pajak restoran sehingga pada tahun 2012 ada kontribusi sebesar 51,47\% dari pajak hotel dan restoran setelah dikurangi dengan kekurangan dari yang dianggarkan untuk pajak reklame.

Dari hasil analisis diatas, sesuai dengan tujuan penelitian ini analisis pendapatan pajak yang diproksikan dengan pajak hote, pajak restoran dan pajak reklame dalam tahun 2010 total nilai kontribusi yang disumbangkan adalah senilai $38,37 \%$. Nilai ini diperoleh karena untuk pajak reklame realisasinya berada di bawah yang ditargetkan sehingga total kontribusi setelah pengurangan dengan kekurangan dari yang ditargetkan adalah sebesar $38,37 \%$. Nilai ini selanjutnya mengalami penurunan di tahun 2011 dimana nilai konntribusi yang disumbangkan hanya sebesar $16,57 \%$ yang berarti bahwa ada penurunan kontribusi pendapatan pajak yang diproksikan dengan pajak hotel,pajak restoran dan pajak reklame sebesar 21,8\%. Akan tetapi nilai ini pada tahun 2012 kembali mengalami peningkatan dimana pada tahun 2012 nilai kontribusi pendapatan pajak yang diproksikan dengan pajak hotel, pajak restoran dan pajak reklame adalah sebesar 51,47\% yang berarti bahwa ada peningkatan dari tahun sebelumnya sebesar 34,9\%.

Berikut ini adalah tabel rekapitulasi pertumbuhan pendapatan pajak selama tiga tahun berturut-turut yang hanya diproksikan dengan pajak hotel, pajak restoran dan pajak reklame: 
Tabel 4

Rekapitulasi Realisasi Pertumbuhan Pajak Daerah

\begin{tabular}{|l|c|c|c|}
\hline \multicolumn{1}{|c|}{ Uraian } & $\mathbf{2 0 1 0}$ & $\mathbf{2 0 1 1}$ & $\mathbf{2 0 1 2}$ \\
\hline Pajak Hotel & Rp..179.072.588 & Rp. 147.548.739 & Rp. 150.371.591 \\
\hline Pajak Restoran & Rp. 923.218.399 & Rp.1.009.856.860 & Rp.1.225.606.544 \\
\hline Pajak Reklame & Rp. 340.708.953 & Rp. 247.469.911 & Rp. 230.617.920 \\
\hline
\end{tabular}

Sumber: Data sudah diolah oleh penulis

Berdasarkan tabel rekapitulasi di atas, maka ada beberapa kesimpulan yang dapat kita peroleh yang akan dijelaskan sebagai berikut:

1. Pajak hotel pada tahun 2010 yang terealisasi adalah sebesar Rp. 179.072.588. Pada tahun 2011 nilai ini mengalami penurunan dari tahun 2010 di mana nilai yang terealiarisasi pada tahun 2011 adalah sebesar Rp. 147.548.739 yang berarti bahwa ada penurunan sebesar $17,60 \%$ dari tahun sebelumnya (2010). Sedangkan pada tahun 2012 nilai pajak hotel yang terealisasi adalah sebesar Rp. 150.371.591. Nilai ini mengalami peningkatan dari tahun sebelumnya (2011) akan tetapi prosentase peningkatan hanya sebesar $1,62 \%$.

2. Pajak restoran pada tahun 2010 yang terealisasi adalah sebesar Rp. 923.218.399. Pada tahun 2011 nilai ini mengalami peningkatan dari tahun 2010 dimana nilai yang terealisasi pada tahun 2011 adalah sebesar Rp. 1.009.856.860 yang berarti bahwa ada peningkatan 9,38\% dari tahun sebelumnya (2010). Sedangkan pada tahun 2012 nilai pajak restoran yang terealisasi adalah sebesar Rp. 1.225.606.544. Nilai ini mengalami pening katan dari tahun sebelumnya (2011) dengan tetapi prosentase peningkatan $21,36 \%$.

3. Pajak reklame pada tahun 2010 yang terealisasi adalah sebesar Rp. 340.708.953. Pada tahun 2011 nilai ini mengalami penurunan dari tahun 2010 dimana nilai yang terealisasi pada tahun 2011 adalah sebesar Rp. 247.469.911 yang berarti bahwa ada penurunan sebesar $27,37 \%$ dari tahun sebelumnya (2010). Dan pada tahun 2012 nilai pajak reklame yang terealisasi adalah hanya sebesar Rp. 230.617.920 yang berarti bahwa ada penurunan dari tahun sebelumnya (2011) sebesar 6,81\%. Kemungkinan penurunan ini disebabkan karena tidak terkontrolnya pemasangan reklame atau karena pajak pajak reklame tidak terbayar oleh wajib pajak karena tidak ada kesadaran pentingnya pajak terhadap pembangunan daerah.

\section{Simpulan}

Berdasarkan analisis hasil dari pembahasan yang telah diuraikan pada sebelumnya, maka kesimpulan yang dapat diajukan adalah sebagai berikut: 
1. Peningkatan penerimaan dari tahun ke tahun mengalami fluktuasi yang kadang naik dan turun. Namun untuk pajak reklame dari tahun ke tahun semakin menurun tanpa mencapai target.

2. Meskipun nial realisasi pajak reklame berada dibawah yang di targetkan, akan tetapi tahun 2010 nilai tambahan atau andil yang diperoleh dari yang ditargetkan sebesar 38,37\%. Nilai ini merupakan kontribusi dari pajak hotel dan pajak restoran dikurangi dengan nilai kekurangan pajak reklame yang ditargetkan.

3. Tahun 2011 nilai tambahan atau andil yang diperoleh dari yang ditargetkan adalah sebesar $16,57 \%$. Nilai merupakan kontribusi dari pajak hotel dan pajak restoran dikurangi dengan nilai kekurangan pajak reklame dari yang ditargetkan.

4. Tahun 2012 nilai tambahan atau andil yang diperoleh dari yang ditargetkan adalah sebesar 51,47\%. Nilai ini merupakan kontribusi dari pajak hotel dan pajak restoran dikurangi dengan nilai kekurangan pajak reklame dari yang ditargetkan.

\section{Saran}

Berdasarkan uraian kesimpulan di atas, maka beberapa saran diajukan dalam penelitian ini adalah sebagai berikut:

1. Pada tahun anggaran berikutnya, hendaknya kinerja Pemerintah Kota Palopo dapat lebih baik lagi dibanding tahun-tahun sebelumnya dengan melakukan berbagai upaya untuk menjamin terpeliharanya kondisi yang mantap, aman, dan kondusif sehingga tuntutan masyarakat untuk membayar pajak sesuai dengan undang-undang dan hukum yang berlaku dan menghendaki transparansi, akuntabilitas dan kepemerintahan yang bebas KKN dapat terwujud.

2. Hendaknya pemerintah Kota Palopo melakukan kontrol terhadap piutang pajak reklame agar dapat tertagih dan mencapai target.

3. Bagi peneliti selanjutnya, hendaknya meneliti secara lebih komplit tidak hanya pada pajak hotel, restoran dan pajak reklame akan tetapi secara lebih luas dapat menambahkannya seperti pajak hiburan, pajak PJU, dan lain-lain.

\section{Daftar Pustaka}

Arif, Bahtiar, Muchlis, Iskandar. 2002, Akuntansi Pemerintahan. Edisi Pertama, Jakarta: Salemba Empat.

Anwar Nasution, 2008 , Perbaikan Pengelolaan Keuangan Negara dalam Era Reformasi.

Bastian. Indra. 2006. Sistem Akuntansi Sektor Publik Edisi 2. Salemba Empat. Jakarta.

Halim, 2008. Akuntansi Sektor Publik Akuntansi Keuangan Daerah, Salemba Empat.

Junaidi. 2011. Pengelolaan Keuangan Daerah Sebuah Kajian Dan Analisis Permendagri Nomor.59 Tahun 2007 Terhadap APBD Kota Palopo Tahun 2009. Skripsi. Palopo Program Sarjana Studi Akuntansi STIE Muhammadiyah Palopo.

Mardiasmo, 2004, Akuntansi Sektor Publik, edisi kedua, Salemba Empat, Yogyakarta.

Mardiasmo, 2002, Perpajakan, Edisi Revisi, Cetakan 
Penerbit: Andi, Jakarta. Undang-Undang No. 17 tahun 2000 tentang Perubahan atas Undang-Undang No. 7 tahun 1983 tentang Pajak Penghasilan sebagaimana telah diubah dengan Undang-Undang No.10 tahun 1994.

M. Noor, Mirawati. 2012. Analisis Laporan Pertanggung Jawaban Pada Pemerintah Daerah Kabupaten Luwu. Skripsi. Palopo Program Sarjana Studi Manajemen STIE Muhammadiyah Palopo.

Nordiawan. Dedi. 2006. Akuntansi Sektor Publik. Salemba Empat. Jakarta.

Rajab, Nurkamar. 2010. Analisis Pajak Pembangunan satu (Konsumen) Terhadap Penerimaan Asli Daerah Kota Palopo. Skripsi. Palopo Program Sarjana Studi Manajemen STIE Muhammadiyah Palopo.

Undang-undang No.22 Tahun 1999 dan Undangundang No.25 Tahun 1999 telah menyebabkan perubahan yang mendasar mengenai pengaturan hubungan Pusat dan Daerah.

Undang-undang Republik Indonesia Nomor 5 Tahun 1974 tentang Pokok-pokok Pemerintah di Daerah

Undang-undang Republik Indonesia Nomor 22 Tahun 1999 tentang Pemerintahan Daerah.

Undang-undang Nomor 22 Tahun 1999 dan Undang-undang Nomor 25 Tahun 1999 tentang Pelaksanaan Otonomi Daerah di Indonesia.

Undang-Undang No 32 tahun 2004 tentang Pemerintahan Daerah.

Undang-undang Nomor 33 Tahun 2004 tentang Perimbangan Keuangan antara Pemerintah Pusat dan Pemerintah Daerah.

Undang-undang No. 28 Tahun 2009 tentang Pajak Daerah dan Retribusi Daerah. http://elib.unikom.ac.id//gdl.php?mod=browse\&o $\mathrm{p}=$ read\&id=jbpunikompp-gdl-

eviferyani.2010. (di akses tanggal 15 juli 2013) pengaruh penerapan sistem akuntansi terhadap akunatabilitas pendapatan pajak daerah di Dinas pendapatan daerah Kota Bandung. Fakultas teknik dan ilmu komputer. Bandung. 